\title{
Effect of Double Cut Management System on Nutrient Uptake of Multicut Oat Cultivars in Irrigated Tracts of North Western Plains of India
}

\author{
Akhil Bharti", Vijay Khajuria, Aaina Sharma, Rakshit Bhagat and Shubham Jamwal \\ Division of Agronomy, Sher-e-Kashmir University of Agricultural Sciences and Technology of \\ Jammu 180009, India \\ *Corresponding author
}

\section{A B S T R A C T}

\section{Keywords}

Cutting

management,

Multicut cultivars,

Nutrient uptake, Oat

Article Info

Accepted:

12 December 2020

Available Online:

10 January 2021
Two year study was conducted at the Divisional Research Farm, Sher-e-Kashmir University of Agricultural Sciences and Technology, Jammu, Chatha during the Rabi season of 2018-19 and 2019-20 to assess the effect of double cut management system on nitrogen, phosphorus and potassium uptake by multicut oat cultivars. It was revealed that cutting management had significant effect on nutrient uptake of all the cultivars and in general double cut treatments recorded higher nutrient uptake than single cut treatments. Among cultivars, JHO-2000-4 recorded highest nitrogen uptake $(103.42 \mathrm{~kg} / \mathrm{ha}$ and $142.44 \mathrm{~kg} / \mathrm{ha})$, phosphorus uptake $(1.08 \mathrm{~kg} / \mathrm{ha}$ and $1.49 \mathrm{~kg} / \mathrm{ha})$ and potassium uptake $(210.66 \mathrm{~kg} / \mathrm{ha}$ and $387.11 \mathrm{~kg} / \mathrm{ha}$ ) in single cut as well as double cutting respectively. However lowest nitrogen, phosphorus and potassium uptake was recorded by JHO-851 (77.17 $\mathrm{kg} / \mathrm{ha}, 0.79 \mathrm{~kg} / \mathrm{ha}$ and $108.71 \mathrm{~kg} / \mathrm{ha}$ respectively) in single cut treatments and JHO$992(74.13 \mathrm{~kg} / \mathrm{ha}, 0.87 \mathrm{~kg} / \mathrm{ha}$ and $241.78 \mathrm{~kg} / \mathrm{ha}$ respectively) in double cut treatments. It was also recorded that at maturity, substantial effect of cutting management was observed in nutrient uptake where single cut treatments were superior to double cut treatments in nutrient uptake by grain and straw.

\section{Introduction}

Oat (Avena sativa L.) is a widely cultivated Rabi fodder crop all over India.It ranks around sixth in the world cereal area, production and productivity followed by wheat, maize, rice, barley and sorghum (Raj and Vyakaranahal, 2014). It not only provides succulent and nutritious fodder for feeding our livestock but also its multicut capabilities allow farmers to take multiple cuttings (up to 2-3 cuts) which enhances green fodder production (Bhilare and Joshi, 2007). India experiences tremendous shortfall in green fodder production. Further, rapid reduction of grassland and pasture lands in recent years, and also due to the poor management of the existing pastures, the fodder deficit has further aggravated (Jat et al., 2015). This shortage has severely affected the health of 
livestock especially the milch animals which ultimately results in poor quality milk and slower growth of dairy industry in the country.

There are various leguminous alternatives to oat crop like Berseem, Lucerne, Cow pea etc. which provide good quantity nutritious fodder. All these leguminous fodders have a serious drawback that is lack of hardiness which results in poor survivability in harsh climates. Moreover, these crops cannot tolerate water stress too hence their cultivation in rainfed areas is prone to vagaries of climate. Whereas oat is a very hardy crop belonging to family Gramineae which can be grown under wide range of conditions and also respond well especially to good soil fertility (Singh, 2016). Owing to its superior growth habit, excellent regeneration capacity and better quality forage, it is a promising forage crop (Kumar and Singh, 2018).It is quick growing, highly nutritious forage crop having crude protein content 12 to 14 percent (Dabhi et al., 2017). Apart from crude protein, oat also provide 30-35 per cent dry matter and supply abundant quantity of vitamin-A and important minerals like Calcium and Iron in addition to energy for the animals (Verma et al., 2016). It can be cultivated in non congenial climates and also requires far less water than leguminous fodders making it highly suitable for cultivation both under irrigated as well as rainfed conditions.

\section{Materials and Methods}

A field experiment was conducted at Research Farm, Division of Agronomy, Shere-Kashmir University of Agricultural Sciences and Technology of Jammu, Main Campus Chatha, in Rabi 2018-19 and 201920 to evaluate nutrient uptake by multicut oat cultivars. The soil of the experimental site was sandy clay loam in texture, slightly alkaline in reaction (7.87) and electrical conductivity in safer range $(0.17 \mathrm{dS} / \mathrm{m})$. Soil was low in organic carbon $(4.57 \mathrm{~g} / \mathrm{kg})$ and available nitrogen $(227.65 \mathrm{~kg} / \mathrm{ha})$ while medium in available phosphorus (12.81 $\mathrm{kg} / \mathrm{ha})$ and available potassium (131.22 $\mathrm{kg} / \mathrm{ha}$ ).

The experimental site was situated in the subtropical Shiwalik foothills of Jammu and Kashmir at $32^{\circ} 40^{\prime} \mathrm{N}$ latitude and $74^{\circ} 82^{\prime} \mathrm{E}$ longitude. The elevation of the site was of 293 meter above mean sea level and normal rainfall of the area was $1115 \mathrm{~mm}$ annually while $253.4 \mathrm{~mm}$ in the crop growth period. The weekly mean temperature of the experimental area in the Rabi season normally rises as high as $39.0^{\circ} \mathrm{C}$ in the $21^{\text {st }} \mathrm{SMW}$ (Standard Meteorological Week) which falls in the month of May and dips down to as low as $5.5^{\circ} \mathrm{C}$ in the first SMW which falls in the month of January. The normal weekly mean maximum (morning) and minimum (evening) relative humidity's ranged from 52.2 to 90.9 per cent and 26.4 to 62.5 per cent respectively.

The experiment had 14 treatments with 3 replications. Seven oat cultivars all released by IGFRI Jhansi (JHO-99-1, JHO-822, JHO2010-1, JHO-2009-1, JHO-851, JHO-2000-4 and JHO-992) were cultivated in randomized block design under two cutting managements at vegetative stage (Single cut at 60 DAS and Double cut at 60 DAS and 105 DAS). The data recorded for various parameters were subjected to statistical analysis according to procedure given by Cochran and Cox (1963). Sowing was done using kera method with 20 $\mathrm{cm}$ row to row spacing. Seed @ $100 \mathrm{~kg} / \mathrm{ha}$ was used for sowing with fertilizers @ 10040-40 (Urea, DAP, MOP). 1/3 ${ }^{\text {rd }}$ of Nitrogen and full dose of phosphorus and potassium was applied at the time of sowing. $1 / 3^{\text {rd }}$ of nitrogen was applied in first split at 30 DAS. Remaining nitrogen was applied in equal 
amounts after every cut. Harvesting at both vegetative stage and final maturity was done manually with a sickle. The methods employed for estimation of nutrients were:

Nitrogen: Modified Kjeldhal's method (Jackson, 1973)

Phosphorus: Vanadomolybdo Phosphoric acid yellow colour (Jackson, 1973)

Potassium: Ammonium acetate method (Jackson, 1973)

\section{Results and Discussion}

\section{Nitrogen uptake}

Data pertaining to nitrogen uptake are presented in Table 1. At 60 DAS, significantly higher nitrogen uptake was recorded in oat cultivar JHO-99-1 under double cut management $(31.02 \mathrm{~kg} / \mathrm{ha})$ which is statistically at par with JHO-2000-4 (29.66 $\mathrm{kg} / \mathrm{ha})$ and JHO-2010-1 (28.56 kg/ha). At 105 DAS, oat cultivar JHO-2000-4 recorded significantly highest nitrogen uptake (49.06 $\mathrm{kg} / \mathrm{ha}$ ) among all the treatments. In grains significantly highest nitrogen uptake was recorded in single cut cultivars and oat cultivar JHO-851 recorded significantly highest nitrogen uptake $(20.98 \mathrm{~kg} / \mathrm{ha})$ among all the cultivars. While in straw significantly highest nitrogen uptake was recorded in single cut JHO-2009-1 (61.67 kg/ha) which was statistically at par with single cut JHO2000-4 (59.00 kg/ha), single cut JHO-992 (56.55 kg/ha) and double cut JHO-2000-4 $(56.38 \mathrm{~kg} / \mathrm{ha})$. However, it was also observed that in general double cut treatments recorded higher nitrogen uptake than single cut treatments.

Nutrient uptake is product of nutrient content and yield hence superior yield and higher nitrogen content in the crop might have resulted in higher nitrogen uptake in respective treatments. Among cutting management, additional cut taken at 105 DAS resulted in additional nitrogen uptake by the plant thus resulting in overall higher nitrogen uptake by the crop.

\section{Phosphorus uptake}

Data with respect to phosphorus uptake has been presented in Table 2. At 60 DAS significantly higher phosphorus uptake was recorded in single cut oat cultivar JHO-2000$4(0.36 \mathrm{~kg} / \mathrm{ha})$ which was statistically at par with single cut JHO-2010-1, double cut JHO99-1，JHO-822，JHO-2010-1，JHO-2009-1 and JHO-992. At 105 DAS, double cut JHO2000-4 recorded significantly higher phosphorus uptake $(0.58 \mathrm{~kg} / \mathrm{ha})$ which was statistically at par with double cut JHO-20101 and JHO-851. In grains significantly highest phosphorus uptake was recorded in single cut treatments and oat cultivar $\mathrm{JHO}-851$ recorded significantly highest phosphorus uptake $(0.25$ $\mathrm{kg} / \mathrm{ha}$ ) among all the cultivars. While in straw significantly higher phosphorus uptake was recorded in single cut JHO-2009-1 (0.60 $\mathrm{kg} / \mathrm{ha}$ ) which was statistically at par with single cut JHO-2000-4 (0.55 kg/ha) and single cut JHO-992 (0.55 kg/ha). However, it was also observed that in general double cut treatments recorded higher phosphorus uptake than single cut treatments.

Higher dry matter and phosphorus content in the respective treatments might have resulted in higher phosphorus uptake by the crop at different growth stages.

Furthermore, additional cut at 105 DAS might have resulted in reduced grain yield in double cut treatments which might have resulted in poor phosphorus uptake by grains in double cut treatments but additional cut resulted in overall higher phosphorus uptake by the crop in double cut treatments. 
Table.1 Effect of cutting managements on nitrogen uptake in multicut oat cultivars (Pooled data of 2 years)

\begin{tabular}{|c|c|c|c|c|c|c|}
\hline \multirow{2}{*}{\multicolumn{2}{|c|}{ Treatment }} & \multicolumn{5}{|c|}{ Nitrogen uptake (kg/ha) } \\
\hline & & \multirow{2}{*}{$\begin{array}{c}60 \text { DAS } \\
25.45\end{array}$} & \multirow{2}{*}{$\begin{array}{c}105 \text { DAS } \\
-\end{array}$} & \multirow{2}{*}{$\begin{array}{c}\text { Grains } \\
11.17\end{array}$} & \multirow{2}{*}{$\begin{array}{l}\text { Straw } \\
44.12\end{array}$} & \multirow{2}{*}{$\begin{array}{l}\text { Total } \\
80.74\end{array}$} \\
\hline $\mathbf{T}_{1}$ & $\begin{array}{l}\text { Oat Cultivar JHO-99-1 with cut at } 60 \text { DAS and at final } \\
\text { harvesting }\end{array}$ & & & & & \\
\hline $\mathbf{T}_{2}$ & $\begin{array}{l}\text { Oat Cultivar JHO-822 with cut at } 60 \text { DAS and at final } \\
\text { harvesting }\end{array}$ & 24.76 & - & 14.82 & 37.64 & 77.22 \\
\hline $\mathbf{T}_{3}$ & $\begin{array}{l}\text { Oat Cultivar JHO-2010-1 with cut at } 60 \text { DAS and at final } \\
\text { harvesting }\end{array}$ & 25.96 & - & 16.80 & 54.48 & 97.24 \\
\hline $\mathbf{T}_{4}$ & $\begin{array}{l}\text { Oat Cultivar JHO-2009-1 with cut at } 60 \text { DAS and at final } \\
\text { harvesting }\end{array}$ & 22.27 & - & 13.09 & 61.67 & 97.03 \\
\hline $\mathbf{T}_{5}$ & $\begin{array}{l}\text { Oat Cultivar JHO-851 with cut at } 60 \text { DAS and at final } \\
\text { harvesting }\end{array}$ & 10.83 & - & 20.98 & 45.36 & 77.17 \\
\hline $\mathbf{T}_{6}$ & $\begin{array}{l}\text { Oat Cultivar JHO-2000-4 with cut at } 60 \text { DAS and at final } \\
\text { harvesting }\end{array}$ & 29.96 & - & 14.46 & 59.00 & 103.42 \\
\hline $\mathbf{T}_{7}$ & $\begin{array}{l}\text { Oat Cultivar JHO-992 with cut at } 60 \text { DAS and at final } \\
\text { harvesting }\end{array}$ & 19.86 & - & 13.92 & 56.55 & 90.33 \\
\hline $\mathbf{T}_{8}$ & $\begin{array}{l}\text { Oat Cultivar JHO-99-1 with cuttings at } 60 \text { DAS, } 105 \text { DAS and } \\
\text { at final harvesting }\end{array}$ & 31.02 & 26.50 & 5.39 & 44.95 & 107.86 \\
\hline $\mathbf{T}_{9}$ & $\begin{array}{l}\text { Oat Cultivar JHO-822 with cuttings at } 60 \text { DAS, } 105 \text { DAS and } \\
\text { at final harvesting }\end{array}$ & 24.14 & 37.58 & 6.40 & 20.97 & 89.09 \\
\hline $\mathbf{T}_{10}$ & $\begin{array}{l}\text { Oat Cultivar JHO-2010-1 with cuttings at } 60 \text { DAS, } 105 \text { DAS } \\
\text { and at final harvesting }\end{array}$ & 28.56 & 41.03 & 7.03 & 45.82 & 122.44 \\
\hline $\mathbf{T}_{11}$ & $\begin{array}{l}\text { Oat Cultivar JHO-2009-1 with cuttings at } 60 \text { DAS, } 105 \text { DAS } \\
\text { and at final harvesting }\end{array}$ & 27.74 & 36.28 & 7.53 & 50.16 & 121.71 \\
\hline $\mathbf{T}_{12}$ & $\begin{array}{l}\text { Oat Cultivar JHO-851 with cuttings at } 60 \text { DAS, } 105 \text { DAS and } \\
\text { at final harvesting }\end{array}$ & 11.41 & 42.74 & 8.22 & 44.14 & 106.51 \\
\hline $\mathbf{T}_{13}$ & $\begin{array}{l}\text { Oat Cultivar JHO-2000-4 with cuttings at } 60 \text { DAS, } 105 \text { DAS } \\
\text { and at final harvesting }\end{array}$ & 29.66 & 49.06 & 7.34 & 56.38 & 142.44 \\
\hline $\mathbf{T}_{14}$ & $\begin{array}{l}\text { Oat Cultivar JHO-992 with cuttings at } 60 \text { DAS, } 105 \text { DAS and } \\
\text { at final harvesting }\end{array}$ & 24.54 & 32.72 & 4.01 & 13.16 & 74.43 \\
\hline SEn & & 0.95 & 1.76 & 0.45 & 2.08 & - \\
\hline CD & $\%)$ & 2.76 & 5.43 & 1.31 & 6.06 & - \\
\hline
\end{tabular}


Table.2 Effect of cutting managements on phosphorus uptake in multicut oat cultivars (Pooled data of 2 years)

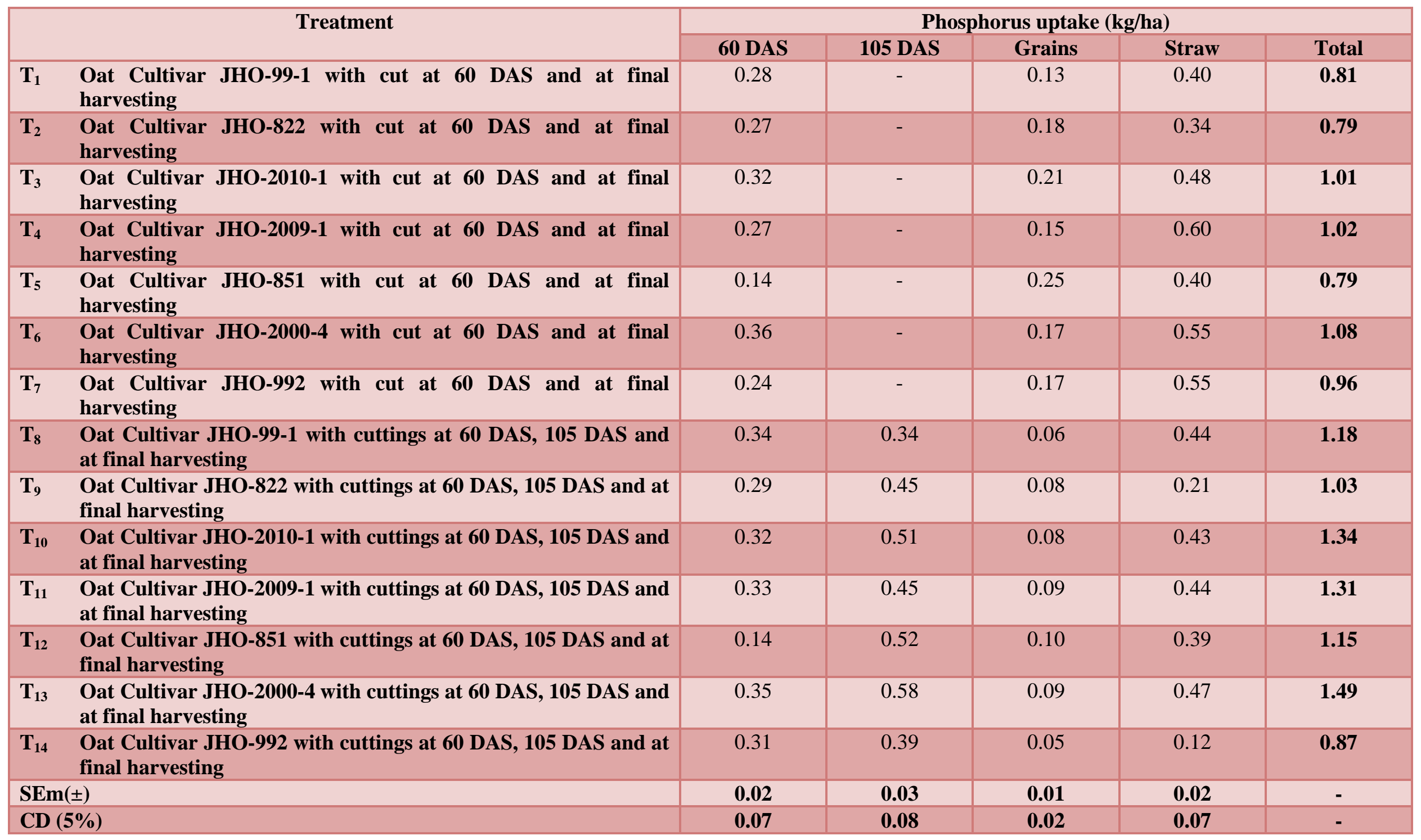


Table.3 Effect of cutting managements on potassium uptake in multicut oat cultivars (Pooled data of 2 years)

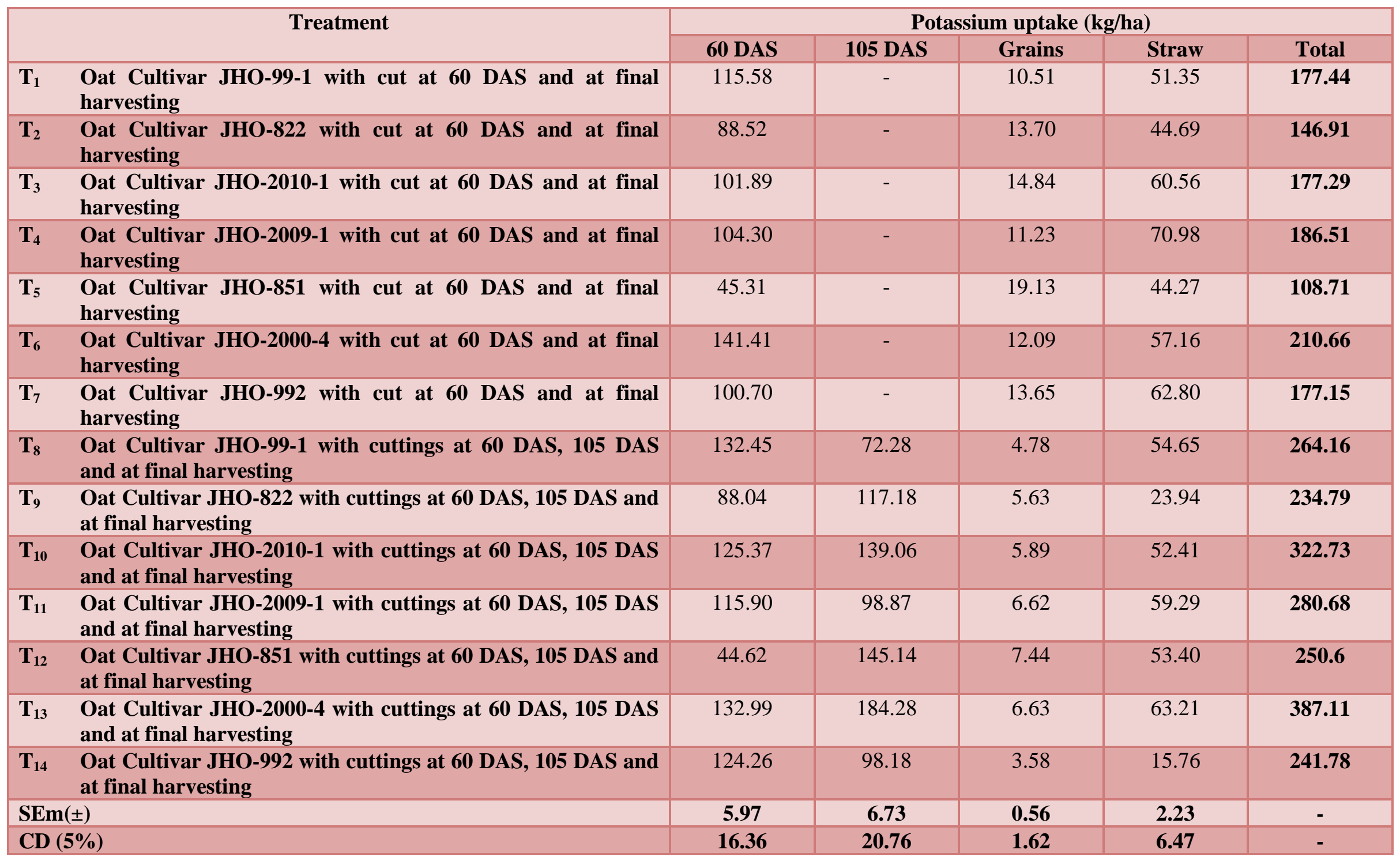


Figure.1 Nitrogen uptake at different stages of crop growth

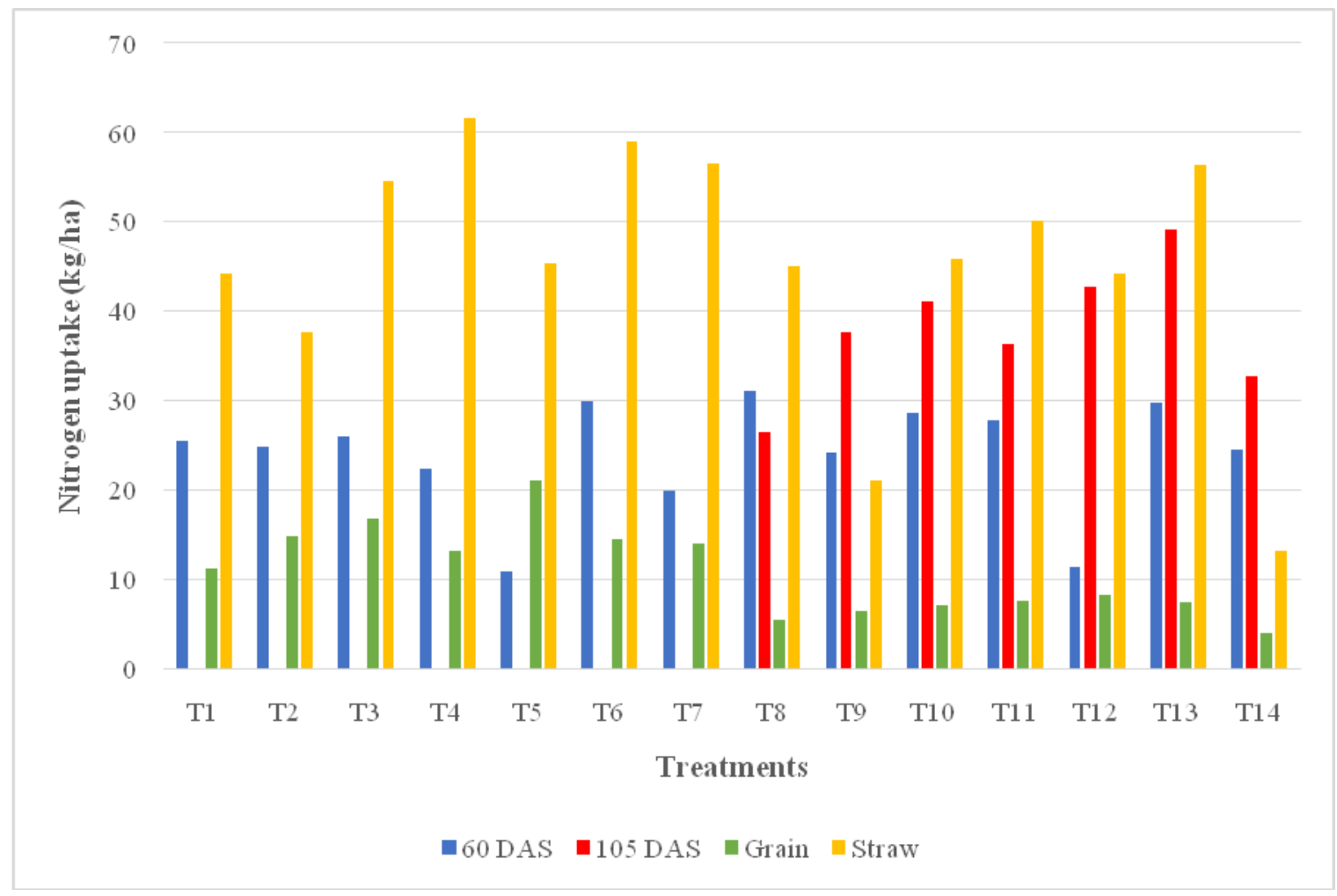

Figure.2 Phosphorus uptake at different stages of crop growth

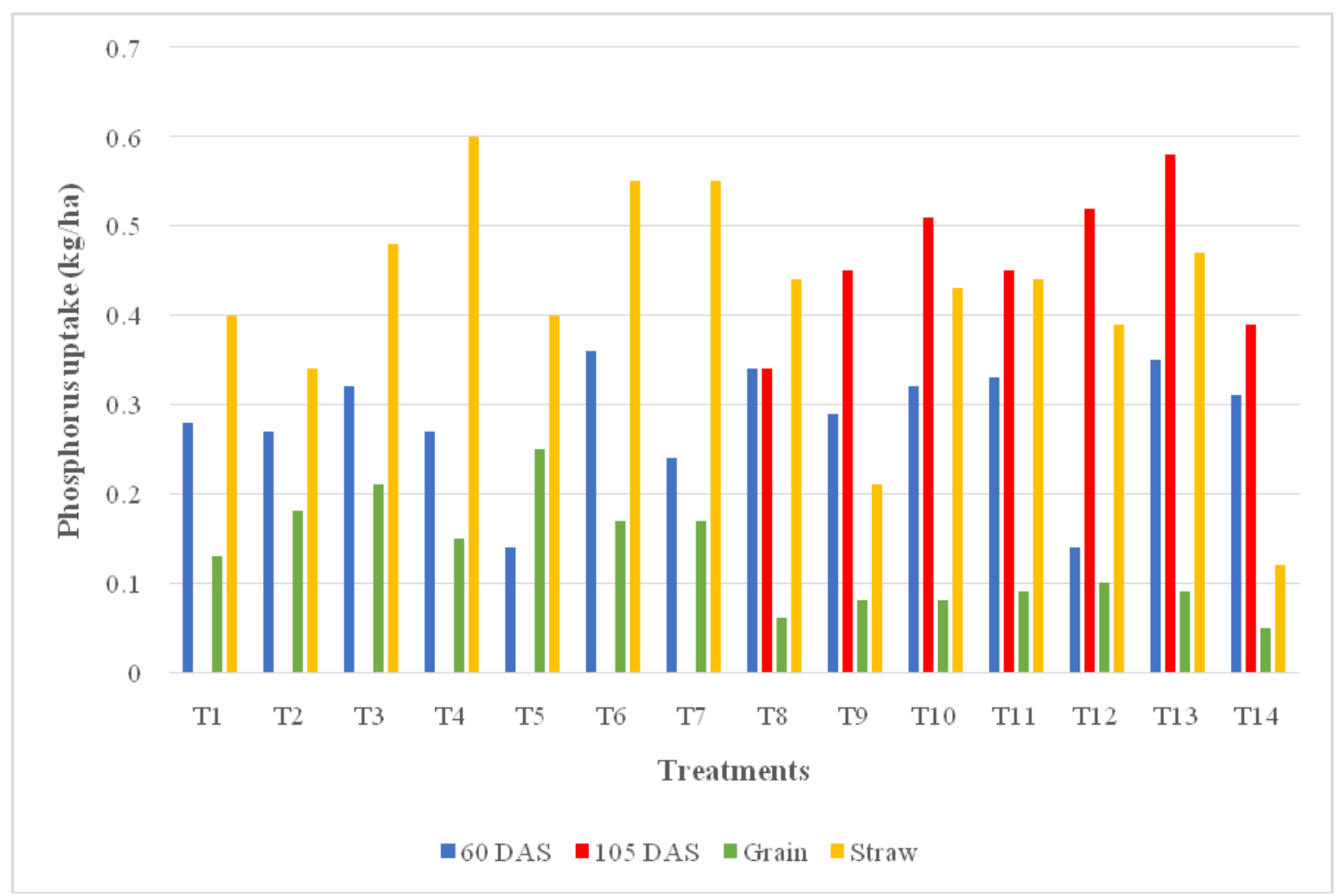


Figure.3 Potassium uptake at different stages of crop growth

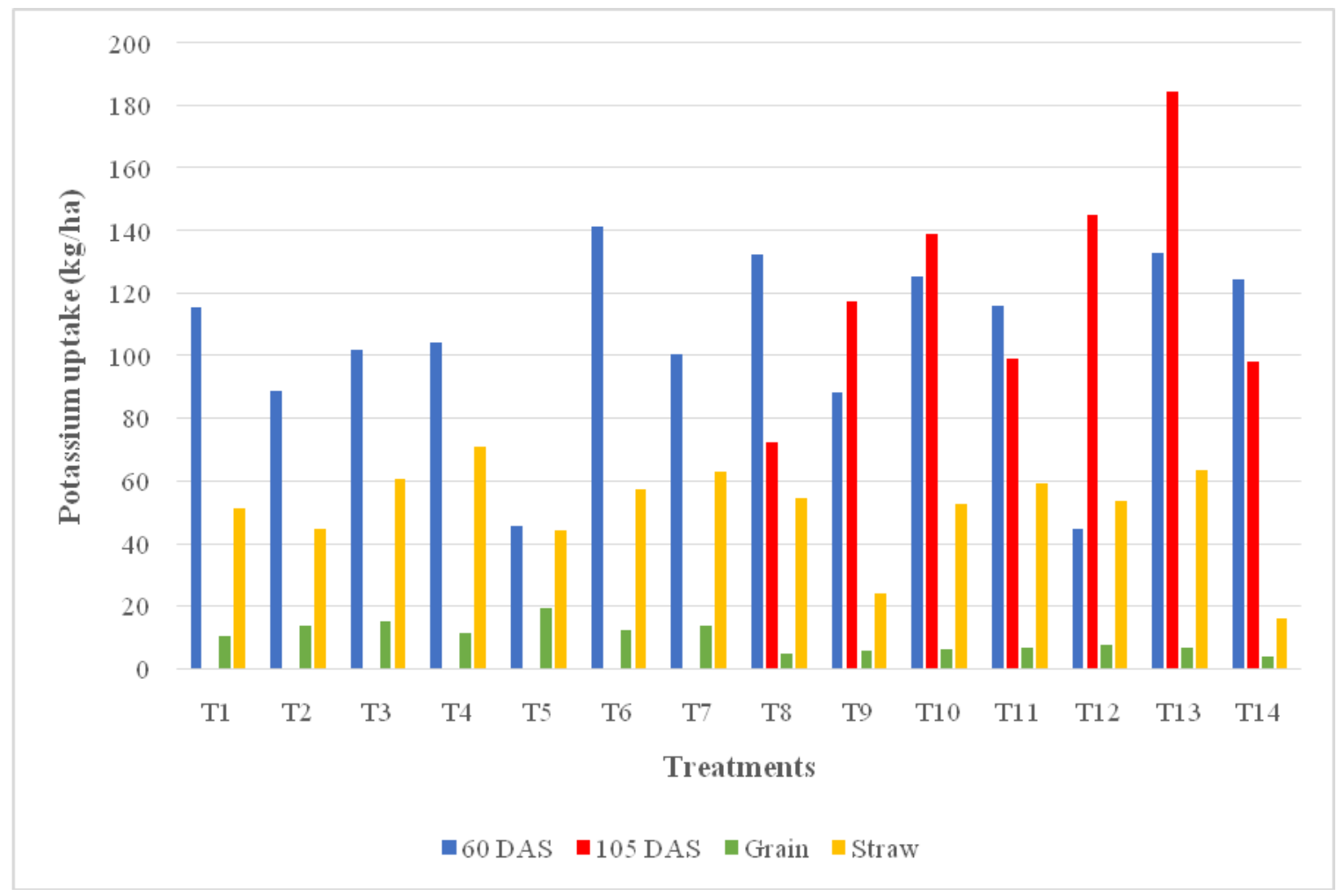

Figure.4 Total nutrient uptake by different treatments

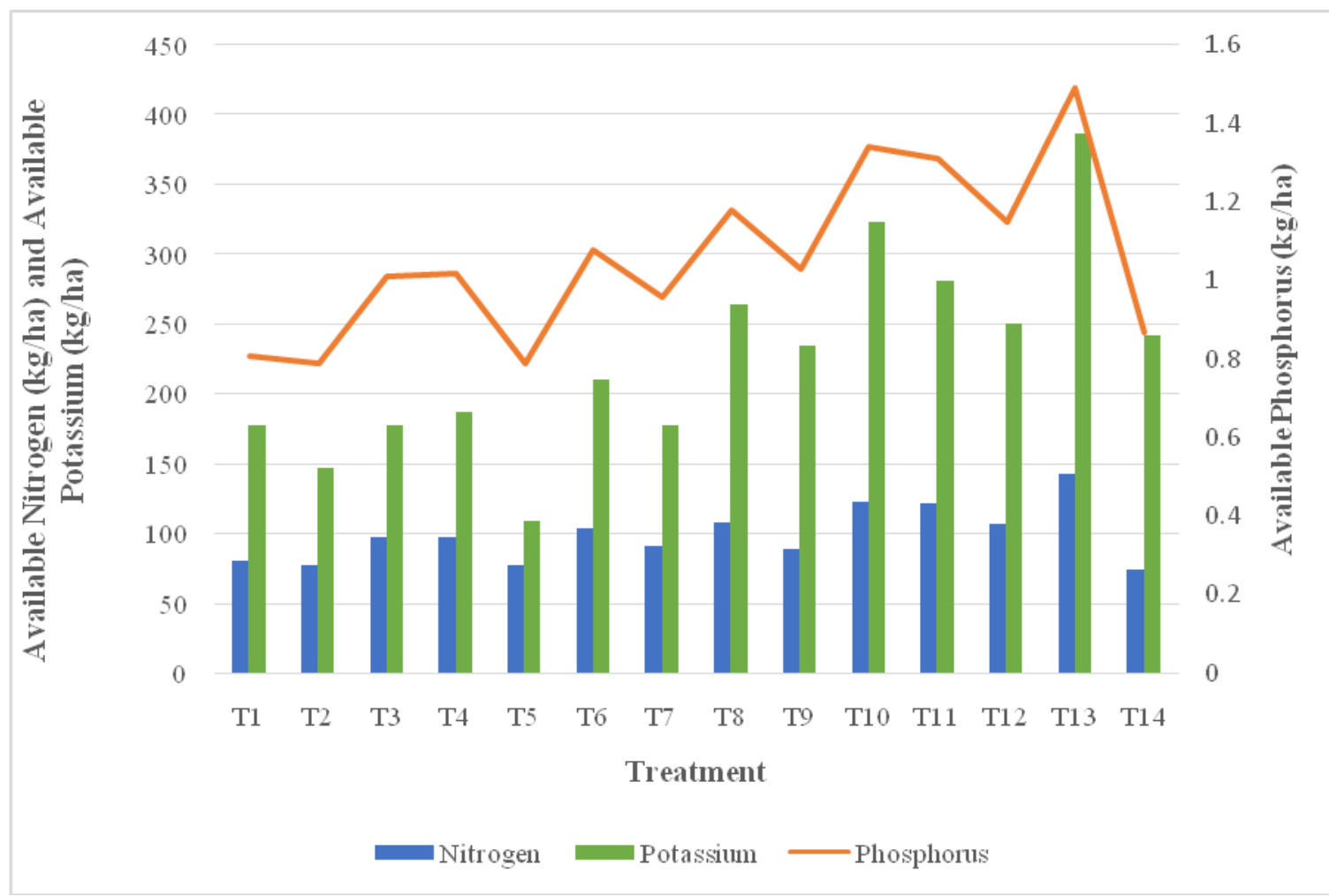




\section{Potassium uptake}

Data with respect to potassium uptake has been presented in Table 3. At 60 DAS significantly higher potassium uptake was recorded in single cut oat cultivar JHO-2000$4(141.41 \mathrm{~kg} / \mathrm{ha})$ which was statistically at par with, double cut JHO-99-1, JHO-2010-1, JHO-2000-4 and JHO-992. At 105 DAS, double cut JHO-2000-4 recorded significantly highest potassium uptake $(184.28 \mathrm{~kg} / \mathrm{ha})$. In grains significantly highest potassium uptake was recorded in single cut treatments and oat cultivar JHO-851 recorded significantly highest potassium uptake $(19.13 \mathrm{~kg} / \mathrm{ha})$ among all the cultivars. While in straw significantly highest potassium uptake was recorded in single cut JHO-2009-1 (70.98 $\mathrm{kg} / \mathrm{ha}$ ). However, it was also observed that in general double cut treatments recorded higher potassium uptake than single cut treatments. It was also observed that overall double cut treatments recorded higher potassium uptake than single cut treatments.

Extreme values of potassium uptake in green fodder (60 DAS and 105 DAS) might be attributed to luxury consumption of potassium by the crop in its vegetative stage resulting in unusually higher uptake in comparison to uptake by grain and straw. It was also observed that double cut treatments recorded overall higher potassium uptake which might be attributed to additional uptake done by the crop when cut was taken at 105 DAS.

On the basis of two year study, it can be concluded that double cut treatments uptake higher amount of nutrients (nitrogen, phosphorus and potassium) from the soil. Among cultivars, irrespective of cutting management, oat cultivar JHO-2000-4 recorded highest nitrogen uptake (103.42 $\mathrm{kg} / \mathrm{ha}$ and $142.44 \mathrm{~kg} / \mathrm{ha}$ ), phosphorus uptake $(1.08 \mathrm{~kg} / \mathrm{ha}$ and $1.49 \mathrm{~kg} / \mathrm{ha})$ and potassium uptake $(210.66 \mathrm{~kg} / \mathrm{ha}$ and $387.11 \mathrm{~kg} / \mathrm{ha})$ in single and double cuttings respectively. Higher uptake of nitrogen, phosphorus and potassium by double cut treatments might be attributed to additional cut taken at 105 DAS which resulted in additional uptake of the nutrients. However, at maturity, grain and straw of single cut treatments resulted in higher uptake of all the nutrients which might be attributed to higher dry matter yield than double cut treatments. Similar findings were also recorded by Jahangir et al., (2017).

\section{References}

Bhilare, R.L. and Joshi, Y.P. 2007. Productivity and quality of oat (Avena sativa) in relation to cutting management and nitrogen levels. Indian Journal of Agronomy, 52: 247-250.

Cochran, W. G. and Cox, G. M. 1963. Experimental Designs. Asia Publishing House, Bombay, India.

Dabhi, M.S., Patel, M.R., Chaudhari, C.R., Patel, V.N. and Patel, P.M. 2017. Response of oat (Avena sativa) varieties to methods of sowing and nitrogen levels on forage yield and quality. International Journal of Chemical Studies, 5(4): 683-686.

Jackson, M. L. 1973. Soil Chemical Analysis. 165-167. Asia Publication House, Bombay.

Jat, R.K., Patel, A.G., Shviran, A. and Bijarnia, A.L. 2015. Response of oat (Avena sativa L.) to nitrogen and phosphorus levels under North Gujarat agro-climatic conditions. Journal of Eco-friendly Agriculture, 10(1): 39-42.

Jehangir, I.A., Panotra, N., Bhat, M.A. and Singh, P. 2017. Nutrient uptake and quality of oats (Avena sativa L.) as influenced by different agronomic practices. Forage Research, 42(4): 263266.

Kumar, B.S. and Singh, R.V. 2018. Nutrient availability of soil influenced by 
nitrogen levels and cutting management in fodder oat (Avena sativa L.) cultivation. International Journal of Chemical Studies, 6(3): 2057-2059.

Raj, M.S.P. and Vyakaranahal, B.S. 2014. Effect of integrated nutrient and micronutrients treatment on plant growth parameters in oat cultivar (Avena sativa L.). International Journal of Plant Sciences, 9(2): 397-400.

Singh, S. 2016. Effect of Organic Matter and
Iron Levels on Yield and Nutrient Uptake by Oat (Avena Sativa L). Asian Journal of Agriculture \& Life Sciences, 1(1): 1-3.

Verma, C., Thanki, J.D., Singh, D. and Chaudhari, S.N. 2016. Effect of nitrogen, bio-fertilizer and farm yard manure on yield and nutrient uptake in oat (Avena sativa). An International Quarterly Journal of Life Sciences,11: 499-501.

\section{How to cite this article:}

Akhil Bharti, Vijay Khajuria, Aaina Sharma, Rakshit Bhagat and Shubham Jamwal. 2021. Effect of Double Cut Management System on Nutrient Uptake of Multicut Oat Cultivars in Irrigated Tracts of North Western Plains of India. Int.J.Curr.Microbiol.App.Sci. 10(01): 12451254. doi: https://doi.org/10.20546/ijcmas.2021.1001.148 